\title{
Belobackenbardia mostovskii sp.n. (Diptera, Psilidae) is the fourth species of an endemic genus found in South Africa
}

\author{
Belobackenbardia mostovskii sp.n. (Diptera, Psilidae) - четвёртый \\ вид эндемичного рода из Южной Африки
}

\begin{abstract}
A.I.Shatalkin
А.И.Шаталкин

Zoological Museum, Moscow State University, Bol'shaya Nikitskaya str. 2, Moscow 125009, Russia. E-mail: shatalkin@zmmu.msu.ru Зоологический музей МГУ, ул. Большая Никитская 2, Москва 125009, Россия.
\end{abstract}

KEY WORDS: Psilidae, Belobackenbardia, systematics, new species, key to species, Cape Floristic Province of Afrotropical Region.

КЛЮЧЕВЫЕ СЛОВА: Psilidae, Belobackenbardia, систематика, новый вид, определительный ключ, Капская флористическая провинция Афротропической области.

ABSTRACT: Belobackenbardia mostovskii sp.n. is described. A key to all species of Belobackenbardia genus is provided.

РЕЗЮМЕ: Описывается новый вид Belobackenbardia mostovskii sp.n. из Южной Африки. Составлена таблица для определения всех видов рода Belobackenbardia.

The genus Belobackenbardia Shatalkin, 2002 includes three species described from South Africa [Shatalkin, 2002]: B. cornicula Shatalkin, 2002, B. munroi Shatalkin, 2002 and B. stuckenbergiorum Shatalkin, 2002. The genus Belobackenbardia is characterized by the following combination of characters: thorax without postmetacoxal bridge (in Chyliza Fallén, 1820 thorax with postmetacoxal bridge); length of wing anterior cubital cell (cua) subequal in length to basal medial cell $(\mathrm{bm})$ as opposed to Chyliza; gena with welldeveloped oval patch of short, white pile situated at some distance from hind margin of eye (synapomorphy; in Chyliza similar brush of shorter white pile extends as narrow fascia to the margin of eye), parafacial (dorsal view) silvery pruinose; antenna short; katepisternum ventrally with one large black seta in front of midcoxa and in dorsal half with patch of white, ventrally directed hair-like setulae (in Chyliza similar white setulae are situated on entire surface of katepisternum). Male genitalia are unique in their structure. Following characters indicate basal phylogenetical position of the genus. Epandrium is massive in comparison with hypandrium; apical forked lobes are actually continuation of epandrium, these lobes could be homologous with surstyli (Figs 14). Hypandrium U-shaped; a pair of lateral sclerites on each side between hypandrium and epandrium could be the derivatives of gonopods (Figs 2, 4: dr gon) [Shatalkin 2002]; phallus upcurved (with phylogenetically primitive dorsal orientation — Griffiths [1972: 37]).

The overwhelming majority of Cyclorrhapha is characterized by the phallus with a ventral orientation of its terminal part. Phallus with dorsal orientation (Figs 2, 4) represents a plesiomorphic (groundplan) condition for Cyclorrhapha and is known among phylogenetically basal Aschiza (adults without ptilinal fissure above base of antennae), in particular, in Platypezinae (Platypezidae), Chalarinae (Pipunculidae), and two syrphid genera Spheginobaccha de Meijere, 1908 and Microdon Meigen, 1803 [Shatalkin, 1995, 2012]. In the three mentioned cyclorrhaphous families (Platypezidae, Pipunculidae and Syrphidae) the derived phallus with a ventral orientation arose in the process of evolution independently.

It can be supposed that the first representatives of Schizophora (adults with ptilinal fissure) were also differ in the plesiomorphic type of genitalia with the dorsal orientation of the terminal part of phallus. Therefore the genus Belobackenbardia will represent the first initial (for Psilidae) representatives of Schizophora that have survived to the present day.

The key for identifying species of Belobackenbardia and the description of Belobackenbardia mostovskii sp.n. are given below. The holotype of new species is deposited in the collection of Zoological Museum of Moscow State University, Russia (ZMUM)

The terminology used in the species descriptions follows Buck [2010], Kirk-Spriggs and Sinclair [2017]. Abbreviations: head setae: frorb - fronto-orbital seta; poc — postocellar seta, $v t$ - vertical seta; mesonotal

How to cite this article: Shatalkin A.I. 2021. Belobackenbardia mostovskii sp.n. (Diptera, Psilidae) is the fourth species of an endemic genus found in South Africa // Russian Entomol. J. Vol.30. No.3. P.342-344. doi: 10.15298/ rusentj.30.3.14 
setae: $d c$ - dorsocentral seta, $n p l-$ notopleural seta, pal — postalar seta, spal - supra-alar seta; genitalia: cerc - cercus; $d r$ gon - derivative of gonopod; epand - epandrium; hypd - hypandrium; pgt — postgonite; ph — phallus; sur — surstyle.

\section{Key to the SPECIES of Genus BELOBACKENBARDIA Shatalkin}

1. Occiput behind ocellar triangle with black spot. Frontoorbital setae absent. Mesonotum yellow with a median black stripe narrow anteriorly and wider, filling the space between dc setae in the posterior part; scutellum with a similar median stripe; metanotum dark brown ........... 2

- Occiput yellow without black spot behind ocellar triangle. 1 or 2 fronto-orbital setae. Mesonotum entirely yellow or with a pair of pale narrow lateral stripes, extending from suture to $d c$; scutellum and metanotum yellow ........... 3

2. 3rd antennal segment with dark spot around arista. Male: epandrium basally with a pair of longer and narrower lobes (ep 1: caudal extremity of abdomen ends with these lobes which are clearly visible on insect); surstyli apically with a pair of short lobes, basally with a pair of narrow conical processes (con pr) oriented dorsally (Figs 1-2). Female: mesonotal median stripe contrasting..... 3rd antennal segment with indistinct dark spot around arista. Male: epandrium basally with a pair of shorter and wider lobes; surstyli apically with a pair of longer lobes, basally without a pair of dorsally oriented narrow conical processes (Figs 3-4). Female: mesonotal median stripe poorly expressed

Belobackenbardia munroi Shatalkin

3. Mesonotum yellow with a pair of pale narrow lateral stripes, extending from suture to $d c$. Fore and middle legs yellow. Abdomen entirely yellow

Belobackenbardia stuckenbergiorum Shatalkin - Mesonotum entirely yellow. Fore tibia grayish, fore tarsus darker; middle tibia darkened in basal half. Abdomen yellow; dorsal side of all tergites broadly dark brown ..

Belobackenbardia mostovskii Shatalkin, sp.n.

\section{Belobackenbardia mostovskii Shatalkin, sp.n.}

TYPE MATERIAL. Holotype: $\bigcirc$, S.Africa, Kwazulu-Natal, PMB Kardoof, $29.318^{\circ}$ S $30.258^{\circ}$ E, 1325 m. 22.XI.2007, M. Mostovski (ZMUM).

DESCRIPTION. Female. Length body $5.8 \mathrm{~mm}$; length wing $5.3 \mathrm{~mm}$.

Head yellow. Frons yellow; narrowly black on each side along eyes; these stripes begin at the level of the posterior edge of the lunula and end at the level of the posterior ocelli. Frontal triangle brownish; ocellar triangle black. Occiput behind ocellar triangle yellow without black spot. Antenna yellow, short; first flagellomere with dark spot around arista; first flagellomere triangular with a straight on upper edge and a slightly convex on lower edge, about 2 times as long as its width. Arista dark brown, almost black, thickened in base, with long rather thick hairs; width of its feathering slightly less than width of first flagellomere. Palpus yellow. Thorax yellow; mesonotum without lateral or median stripes, metanotum without brownish spot; black hairs under hind spiracle absent. Katepisternum ventrally with one large black seta in front of mesocoxa and in upper portion with patch of white, ventrally directed hair-like setulae. Legs yellow; fore tibia grayish, fore tarsus darker; middle tibia darkened in first half, middle tarsus grayish; hind tibia and tarsus distinctly darkened. Middle tibia with 1 spur. Wing yellowish, veins yellow with wide yellow edging; correspondingly, wing apex in the front half yellow. The wavy flexion line extending from subcostal break to posterior end of basal medial cell $(\mathrm{bm})$ and crossing vein $\mathrm{M}_{4}$ near apex of basal medial cell $(\mathrm{bm})$; this flexion line is very poorly developed, visible in the form of thinning of veins and traces on the interveinal space in the posterior part of the wing. Halteres yellow. Abdomen yellow; tergites 1-6 dorsally broadly dark brown, narrowly yellow along posterior margin; tergite 7 with two dark brown spots on sides; lateral margins of abdominal tergites straight.

Chaetotaxy. $2 v t$, pvt absent, 1 very large frorb directed dorsally; $1 \mathrm{npl}, 1 \mathrm{spal}, 1 \mathrm{pal}, 1 \mathrm{dc}$, scutellum with 2 large marginal setae and with a pair of hair-like ones above. All setae black.

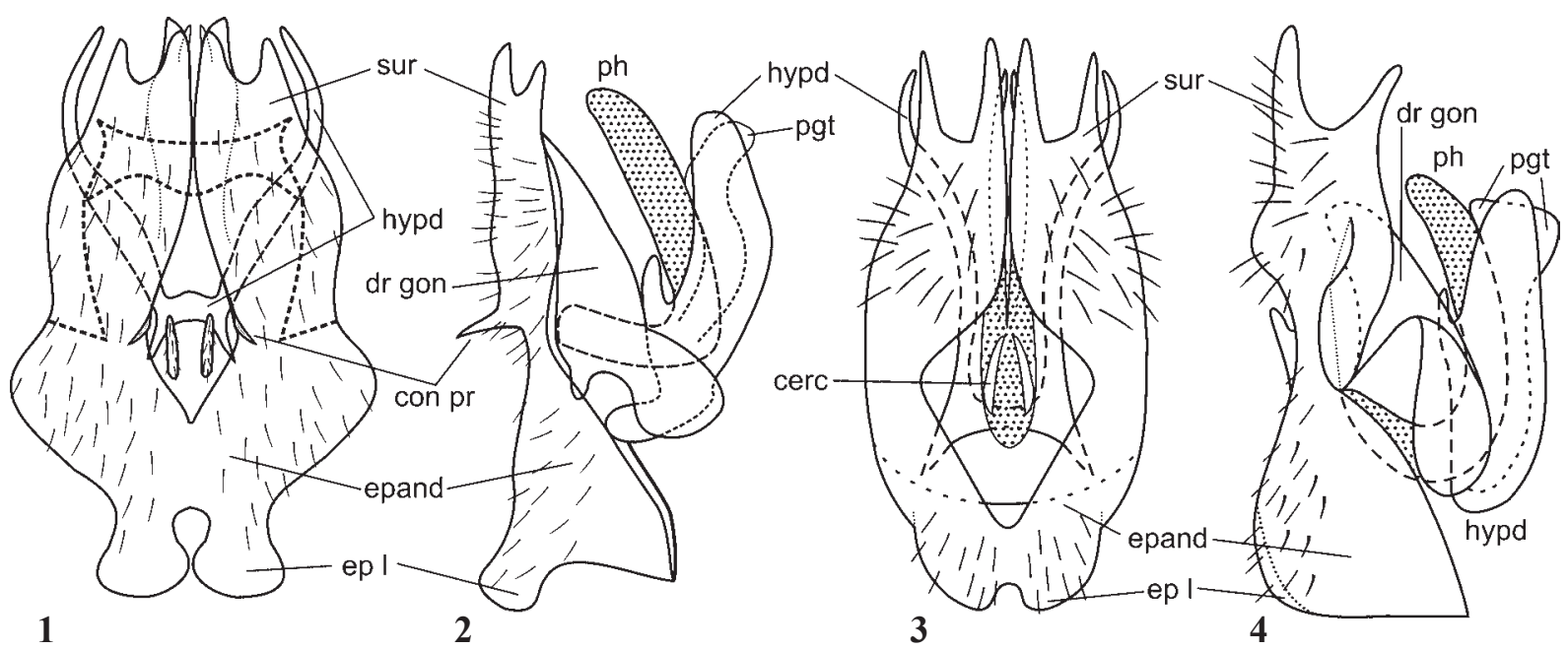

Figs 1-4. Male terminalia of Belobackenbardia: 1-2 - B. cornicula; 3-4 - B. munroi; $1,3-$ dorsal view; 2 , $4-1$ lateral view. Abbreviations: cerc — cercus; con pr — conical process of surstyle; dr gon — derivative of gonopod; epand — epandrium; ep 1 - lobes of epandrium; hypd — hypandrium; pgt — postgonite; ph — phallus; sur — surstyle.

Рис. 1-4. Гениталии самцов Belobackenbardia: 1-2 - B. cornicula; 3-4 - B. munroi; 1,3 - сверху; 2, 4 - сбоку. Обозначения: cerc — церк; con pr — конический вырост сурстиля; dr gon — производное гонопод; ераnd — эпандрий; ер 1 - доли эпандрия; hурd — гипандрий; pgt — постогонит; ph — фаллус; sur — сурстиль. 
MALE unknown.

DIAGNOSIS. As it is clear from the identification key, among the four known species, the new species is closely related to $B$. stuckenbergiorum. Both species differ from the other two, B. cornicula and B. munroi, in the absence of a black spot on the occiput behind ocellar triangle and of the black median stripe on the mesonotum, scutellum and metanotum. B. stuckenbergiorum differs well from the new species by a completely yellow abdomen, in the presence of a pair of brown stripes on the mesonotum and in having fore and middle legs yellow, non-darkening.

ETYMOLOGY. The new species is named to honor the dipterist Dr. M.B. Mostovski.

Acknowledgements. I am grateful to Dr. Mikhail Borissovich Mostovski (The Steinhardt Museum of Natural History and Israel National Center for Biodiversity Studies, Israel) for assistance with the material. I am grateful to T.V. Galinskaya (Entomology Department of the Lomonosov Moscow State University) for the English manuscript proofreading. The work is supported by the Scientific Project of the State order of the Government of
Russian Federation to Lomonosov Moscow State University No. 121032300105-0.

\section{References}

Buck M. 2010. 60. Psilidae (rust flies, psilid flies)//Brown B.V., Borkent A., Cumming J.M., Wood D.M., Woodley N.E., Zumbado M.A. (eds.). Manual of Central American Diptera. Vol.2. Ottawa: NRC Research Press. P. 837-842.

Griffiths G.C.D. 1972. The phylogenetic classification of Diptera Cyclorrhapha, with special reference to the structure of the male postabdomen. Series Entomologica 8. The Hague: W. Junk NV. 344 p.

Kirk-Spriggs A.H., Sinclair B.J. (Eds) 2017. Manual of Afrotropical Diptera. Vol.1. South African National Biodiversity Institute. xiv, $425 \mathrm{p}$.

Shatalkin A.I. 1995. Palaearctic species of Pseudopomyzidae (Diptera) // Russian Entomological Journal. Vol.3 (for 1994). P.129-145.

Shatalkin A.I. 2002. Afrotropical Psilidae (Diptera). 1. Genera Belobackenbardia gen.n. and Psila Meigen, 1803 // Russian Entomological Journal. Vol.10 (for 2001). P.417-424.

Shatalkin A.I. 2012. [The homologies in structure of male genitalia of Cyclorrhapha (Diptera)] // Caucasian Entomological Bulletin. Vol.8. No.2. P.321-327 [in Russian]. 